\title{
Quem salva quem? Saviour siblings e seus aspectos bioéticos
}

\section{Who saves whom? Saviour siblings and its bioethical aspects}

\author{
Isabela De Marco Leandro' ${ }^{1}$ \\ Thaissa Souza da Silva ${ }^{2}$ (1) \\ Flávia Fernandes Barbosa ${ }^{3}$ (1) \\ Ana Carolina Custodio de Barros 4 (1) \\ Monaliza Mendes Carvalho da $\mathrm{Cruz}^{5}$ (1) \\ Luisa de Oliveira Garcia ${ }^{6}$ (i)
}

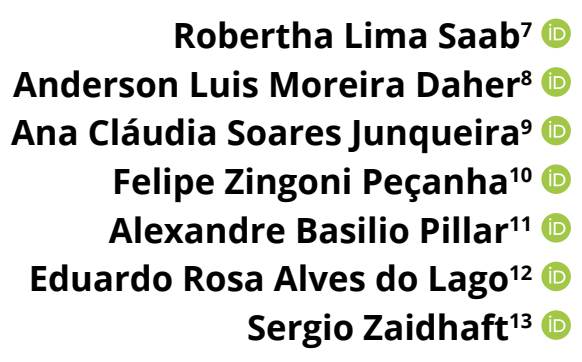

1-12Universidade Estácio de Sá (Rio de Janeiro). Rio de Janeiro, Brasil. isabelademarco.l@gmail.com, souzathai96@gmail.com, fernandesflaviab@gmail. com, carolcdbarros@gmail.com, monalizamcarvalho@gmail.com, luisaogf@gmail.com, roberthasaab@gmail.com, anderson.daher10@gmail.com, aninhasjunqueira@gmail.com, zingonao@hotmail.com, xandepillar@gmail.com, eduardolagorj@gmail.com

${ }^{13}$ Autor para correspondência. Universidade Estácio de Sá (Rio de Janeiro). Rio de Janeiro, Brasil. sergio.zaidhaft@gmail.com

RESUMO | INTRODUÇÃO: A ideia do artigo surgiu durante uma disciplina na qual os alunos foram organizados em grupo para a discussão de um assunto dentro da temática da bioética, sendo o assunto escolhido "saviour siblings". O "saviour sibling" é uma criança concebida na esperança de que ela seja geneticamente compatível com um irmão mais velho que possui alguma patologia cujo tratamento consista na doação de tecidos. OBJETIVO: Debater a concepção de irmãos doadores e a delicadeza e complexidade do tema na perspectiva bioética. METODOLOGIA: Revisão bibliográfica realizada em agosto de 2019, na base de dados PubMed, utilizando o descritor "saviour siblings." O material obtido foi utilizado para discussão e elaboração de um caso clínico. RESULTADOS: Foram encontrados 40 artigos, nove excluídos pelo resumo por divergirem do tema. O caso clínico foi desenvolvido coletivamente e os autores incumbidos de se colocarem no lugar dos envolvidos nesta decisão e narrar os possíveis pensamentos e sentimentos em cada um deles. Em seguida, utilizaram-se as referências bibliográficas para discutir o caso clínico construído, sob a perspectiva bioética. CONCLUSÃO: São delicadas e complexas as questões bioéticas relacionadas ao tema saviour siblings. Por um lado, há o benefício de se salvar uma criança doente e trazer alívio a seus pais. Por outro, esta técnica pode remeter a práticas eugênicas como a seleção de indivíduos a partir de sua genética. A perda de autonomia do irmão salvador precisa ser enfoque de futuras discussões éticas a fim de proteger seus direitos. É imprescindível o ensino de Bioética para a formação de profissionais da saúde.

PALAVRAS-CHAVE: Bioética. Concepção de doadores. Genética.
ABSTRACT | INTRODUCTION: The idea of the article arose during a course in which students were organized in groups to discuss a bioethics subject and the subject chosen was "saviour siblings". "Saviour sibling" is a child conceived in the hope of being genetically compatible with an older brother who has some pathology whose treatment consists of the donation of tissues. OBJECTIVE: To debate the conception of saviour siblings and the delicacy and complexity of the theme from a bioethical perspective. METHODOLOGY: Literature review carried out in August 2019, in the PubMed database, using the keyword "saviour siblings". The material obtained was used for discussion and elaboration of a clinical case. RESULTS: 40 articles were found, nine of which were excluded from the abstract for diverging from the topic. The clinical case was developed collectively and the authors delegated with putting themselves in the place of those involved in this decision and narrating the possible thoughts and feelings of each one of them. Then, bibliographic references were used to discuss the constructed clinical case, from the bioethical perspective. CONCLUSION: Saviour siblings related bioethical issues are delicate and complex. On the one hand, there's a benefit of saving a sick child and bringing relief to the parents. But, on the other hand, this technique can bear on eugenic practices such as the selection of individuals based on their genetics. The violation of the saviour sibling's autonomy needs to be the focus of future ethical discussions in order to protect his rights. Teaching bioethics is essential for the training of health professionals.

KEYWORDS: Bioethics. Donor conception. Genetics. 


\section{Introdução}

A ideia para o presente artigo surgiu durante a disciplina de Seminário Integrado, que é ministrada do primeiro ao oitavo período no Curso de Medicina de uma universidade privada. Nessa disciplina os alunos se reúnem em grupos e devem escolher um assunto de estudo que seja relacionado com o tema do semestre, sendo orientados por um professor do período. Para os alunos do sétimo período, semestre em que foi realizado o trabalho, a Bioética - uma das disciplinas do período, com o título "Bioética Aplicada à Prática Médica" - é o assunto-base. Dentro dela, foi escolhida pelo grupo a temática do "irmão salvador", para que fossem discutidas suas implicações bioéticas. Para tal, os alunos construíram um caso clínico, permitindo que a partir do mesmo fossem elaborados e discutidos dilemas bioéticos, como proposto.

O "saviour sibling", também conhecido como "irmão salvador" ou "bebê medicamento" é uma criança concebida na esperança de que ela seja geneticamente compatível com um irmão mais velho que possui alguma patologia, como anemia aplásica, talassemia, leucemias, linfomas, entre outras $s^{1-3}$. Essas doenças necessitam de transplantes de tecidos, como células-tronco do cordão umbilical, sangue periférico ou medula óssea para seu tratamento ${ }^{1.4}$.

Esse processo pode ser realizado de forma natural (neste caso, existe $25 \%$ de chance de ser um doador compatível) ou por diagnóstico genético pré-implantacional (DGPI) com 100\% de garantia de compatibilidade $^{5-7}$. Esse método foi desenvolvido com o objetivo de criar novas possibilidades que evitassem a transmissão de mutações genéticas responsáveis por doenças hereditárias e combina fertilização in vitro (FIV), diagnóstico genético e citogenética. Ocorre uma tipificação do HLA (proteína usada pelo sistema imune para identificar células próprias), garantindo que a criança gerada tenha compatibilidade com o irmão já existente ${ }^{1,6}$.

O primeiro caso descrito na literatura é de Adam Nash, nascido em 2000 nos Estados Unidos. Células-tronco do seu cordão umbilical foram suficientes para o tratamento de sua irmã. Já em outros casos este procedimento pode não ser suficiente, sendo necessário o transplante de outros tecidos. Desde então, diversos países como EUA, França, Reino Unido, Austrália,
Brasil e outros, têm tentado acompanhar esse avanço na medicina. Os benefícios para os pais e o filho já nascido são muito mais claros do que os do concepto ${ }^{12} \mathrm{e}$ gerar uma criança com a finalidade específica de salvar um irmão é algo absolutamente recente na história da Humanidade. Esse avanço há de ser obrigatoriamente acompanhado pela discussão de seus aspectos éticos e bioéticos, para, além de regularizar a técnica, garantir os direitos da criança a nascer, sua segurança e integridade física e mental, buscando evitar sua instrumentalização, além de viabilizar o possível tratamento para a criança doente $3,6,9,-11$.

\section{Objetivo}

Debater a concepção de irmãos doadores e a delicadeza e complexidade do tema na perspectiva bioética.

\section{Metodologia}

A revisão bibliográfica sobre o tema foi realizada em agosto de 2019, na base de dados PubMed, tendo sido utilizado o descritor "saviour siblings", sem limite de data, tipo de publicação, língua e periódico. Foram encontrados 40 artigos. Destes, 9 foram excluídos pelo resumo por divergirem do tema. Assim sendo, restaram 31 artigos: 19 a partir de 2010 e 12 anteriores a 2009. O grupo fez a leitura e discussão de todos e selecionou os 19 mais relevantes - dando preferência aos mais atuais - que originaram a bibliografia do presente artigo. Além disso, consultaram-se textos de bioética para a fundamentação dos argumentos utilizados, constituindo o restante da bibliografia.

Após a discussão do tema, houve a elaboração de um caso clínico com anuência da instituição onde a experiência educacional foi desenvolvida. Para tal, os autores deste trabalho foram incumbidos de se colocarem no lugar dos envolvidos nesta decisão, ou seja, pai, mãe, filho doente, médica e irmão salvador, e narrar os possíveis pensamentos e sentimentos em cada um deles, sendo posteriormente elaborada uma síntese destas criações com todas suas semelhanças, diferenças e contradições. Em seguida, utilizaram-se as referências bibliográficas selecionadas para discutir o caso clínico construído, sob a perspectiva bioética. 


\section{Caso clínico}

Joana, 35 anos, enfermeira, e Carlos, 32 anos, engenheiro, com um ano de casados, descobriram que estavam grávidos. Sempre desejaram uma grande família, mas, ao mesmo tempo, preocupados com a disponibilidade de tempo por conta de suas carreiras e com a situação financeira necessária para sustentar confortavelmente uma família, acabaram optando por ter apenas uma filha. Nomearam-na Alice e esses primeiros anos foram repletos de felicidade.

Aos cinco anos, Alice começou a se sentir cansada. Depois, a reclamar de dor nos ossos. Seus pais levaram-na ao médico e este a diagnosticou com "dores de crescimento". Inconformados, foram a outro médico, que deu início à investigação. Logo, Alice foi diagnosticada com leucemia mieloide aguda. Joana largou o emprego e dedicou-se a cuidar da filha em tempo integral. Para arcar com os custos, Carlos começou a trabalhar cada vez mais. Os tratamentos não surtiam resultados e a saúde de Alice decaía a cada nova tentativa.

Um ano depois do diagnóstico, a Dra. Marta chamou Joana e Carlos em seu consultório. Discursou sobre as avançadas técnicas científicas, mas também falou que mesmo hoje a medicina ainda encontrava muitas barreiras e estava muito longe de conseguir salvar diversos casos - sendo Alice um deles. Sua última opção era um transplante de medula óssea. Carlos logo se prontificou a doar e Joana começou a chorar. Ela sabia que a probabilidade de que um deles fosse compatível era pequena, e que também seria muito difícil encontrarem um doador a tempo. Como era inserida na área da saúde, questionou a possibilidade de terem outro filho, um cuja compatibilidade genética poderia ser $100 \%$ garantida com DGPI. Dra. Marta, então, explicou aos angustiados pais que sim: com o avanço técnicocientífico, esse procedimento poderia ser a chance de cura da Alice, mas também explicitou que os pais deveriam pensar nas possíveis consequências de ordem psicológica para o novo filho, por ter sido gerado primordialmente para satisfazer a necessidade dos pais de tentarem salvar sua irmã.

Carlos e Joana ponderaram os prós e contras e com alguns receios, mas tomados pelo desespero, resolveram seguir adiante. Depois de todos os procedimentos, Joana conseguiu, enfim, engravidar. Com a evolução da gestação, toda a família foi se preparando e realizou-se o necessário para Alice estar apta a receber o transplante de medula óssea, que viria do cordão umbilical de seu irmão, e, quando Guilherme nasceu, os procedimentos começaram.

\section{Pensamentos e sentimentos (por um lado / por outro lado)}

A partir de discussões sobre como montar o caso clínico, o grupo se propôs a imaginar os dilemas mentais dos envolvidos na geração do bebê salvador. Chamaremos este exercício de 'pensamentos e sentimentos', e eles têm como princípio serem livres de tempo e espaço, podendo ser inclusive pensamentos do bebê ainda não concebido.

\section{Pai}

Por um lado, sinto que a qualquer momento minha esposa vai ficar doente com tantas preocupações e vejo como minha filha está triste, mas também me sinto ausente por causa do trabalho. Na verdade, me sinto sem direção, pois não sei como ajudar minha família. Quero mais que tudo salvar minha filha, nenhuma criança merece passar por tudo isso, muito menos uma outra, que seria gerada com o puro intuito de salvar a primeira. E se depois de tudo, de uma gravidez difícil, o filho acabar não sendo compatível? Continuaremos a produzir filhos, até que um seja? Como será a vida dessas crianças, minha vida, de minha esposa, com todos esses procedimentos, que podem nem dar certo no final das contas, e que envolvem muito sofrimento? Pode ser também que seja o destino de nossa filha que a vida dela acabe assim - cedo- e que seja melhor que a gente sofra logo e aceite isso agora, do que passar anos, talvez a vida toda desses filhos num sofrimento interminável. Depois que a criança nasceu: Não acredito que tivemos outro filho à toa, que nossa menina vai morrer do mesmo jeito e essa era nossa última esperança.

Por outro lado, penso: Ele terá orgulho de ser um bebê salvador... Quem não se orgulharia? Será que devemos ou não falar para ele sobre seu propósito de vida? É certo contar, independentemente do que aconteça com nossa filha mais velha? Ainda assim, é melhor contar o verdadeiro propósito de seu nascimento assim que tiver algum entendimento sobre a situação, não vamos nos precipitar. Afinal, quem não ficaria feliz sabendo que pode salvar a vida de um irmão? Vai dar certo. Tem que dar! 


\section{Mãe}

Por um lado, nossa única filha tem uma doença que pode matá-la. A doença é grave e ela precisa de um transplante de medula para que possa melhorar. Por favor, meu Deus, faz minha filha ficar bem, faz ela melhorar. O senhor pode tirar tudo que é meu, até a minha própria vida, mas deixa ela ficar bem. A ideia de fazer uma FIV e dessa forma termos uma criança compatível para salvar nossa filha pode ser absurda, mas acho que combina com o que tem acontecido com a gente. A dor de imaginar perder um filho é maior do que qualquer consequência, mas o que essa criança gerada vai pensar? Poderíamos não contar, mas e se ele descobrir por terceiros o que fizemos? Vai nos odiar? Será preciso realizar diversos procedimentos, não há como esconder isso! Será que ele vai se sentir rejeitado ou até mesmo menos querido que nossa filha mais velha? Ao mesmo tempo, essa vida pode acabar salvando a minha neném. É óbvio, mas não há a menor dúvida que, se tem uma chance de salvá-la, por mais incerta que seja, eu vou fazer isso. Temos que tentar tudo. Ela é a coisa mais importante da minha vida, não aceito perdê-la. Eu nunca pensei em ter outro filho, não com tudo que está acontecendo, mas é minha última opção. Eu preciso esgotar todos os meus esforços. Minha filha está no hospital e eu aqui fazendo teste em um palitinho.

Depois que a criança nasceu: Sinto que deixei meu marido e meu outro filho de lado apesar de amá-los também. Eu nunca perguntei como ele se sente sobre isso, pois sempre achei que era um dever dele com nossa família. Será que eu não deveria ter buscado um auxílio psicológico? Por que não busquei aceitar que minha filha ia morrer?

Por outro lado, após um ano sem sucesso buscando um doador compatível de forma tradicional e realizando diversos tratamentos, surgiu uma ideia que pode salvar nossa filha. Se eu e meu marido concordarmos, poderemos ter uma criança a partir de uma FIV e ela será compatível, assim poderemos salvar nossa filha mais velha. Essa é nossa única esperança, sua vinda trará alegria para a nossa família e a vida da minha filha de volta.

Essa decisão, de criar uma criança compatível, foi a melhor que eu e meu marido poderíamos tomar. Com certeza ele gostará de ter uma irmã e ele não vai se importar de ajudá-la, ele sabe que é por uma causa maior, pela vida de outra pessoa. É claro que temos que tentar! Estou preparada para lidar com todas as questões psicológicas que essa escolha possa trazer, de forma a mostrar aos meus dois filhos o quanto são incondicionalmente amados por nós.

Depois que a criança nasceu: a mais velha só está viva por sua causa e você só está vivo por causa dela. Entenda que eu amo vocês dois da mesma forma. A mais velha por pouco não morreu, pois não havia mais doadores compatíveis com ela. Sempre quis ter uma família grande e unida. Afetividade nunca faltou por parte de mim e de seu pai. Para mim, você é o bebê do amor.

\section{Médica}

Por um lado, acompanhei o nascimento do primeiro bebê-medicamento no Brasil em 2012. Eu vejo a reprodução assistida como uma alternativa viável à resolução desses problemas. Podemos selecionar um embrião saudável histocompatível com a criança primogênita. A lei brasileira respalda os pais quanto ao planejamento familiar desde que respeitada a dignidade da pessoa humana e o exercício da parentalidade responsável. Constatei o alívio dos pais ao terem seu filho doente salvo e o irmão salvador - até onde tive conhecimento - não apresenta qualquer problema relativo a ter sido gerado com este fim.

Por outro lado, será que a humanidade que queremos é a que seleciona indivíduos a partir de sua genética? Se hoje selecionamos um embrião através de sua genética compatível com a de um irmão, será que isso poderá abrir as portas para um futuro no qual embriões sejam selecionados apenas de acordo com seus genes? Hoje pensa-se em genes compatíveis - quem sabe se no futuro não se pensará em genes "melhores"? Seres humanos não são vegetais a serem melhorados geneticamente para que se tornem perfeitos para consumo. O caminho da seleção genética é arriscado, seja qual for o motivo dessa seleção, e aventurar-se nesse caminho é perigoso. Basta lembrar dos tempos sombrios que resultaram da última vez em que a teoria eugenista foi implantada como política de países. E eu nisso tudo? O que digo aos pais? Como os oriento? E será que o bebê salvador do caso que acompanhei sabe de sua história? Seus pais foram orientados sobre como conversar com ele? É para dizer a ele? Alguém já escreveu sobre isso? Preciso ver o que já foi publicado sobre o follow-up dessas crianças e suas famílias. 


\section{Filha Doente}

Por um lado, a parte mais difícil de ter uma doença é o sofrimento que ela causa nas pessoas que amo. Eu quero muito viver, mas se for para fazer meu irmão passar por um monte de procedimentos dolorosos, prefiro partir. Vejo meus pais esgotados, sempre me acompanhando nos hospitais. É como se eu fosse um peso para toda a minha família. Logo, acabar submetendo meu irmão a procedimentos dolorosos e sofrimento psicológico me parece um preço alto demais. Odeio que passe por tudo isso, me sinto culpada e fico apavorada só de pensar que eu possa ser a causa do sofrimento dele.

Por outro lado, tenho uma doença que pode me matar. Por que logo eu fui ter essa doença? Isso não é justo. Meus pais me falaram que vão ter mais um filho e esse meu irmão poderá me ajudar e com isso vou melhorar da minha doença. Se eu quero um irmão? É claro que eu quero! Se, além disso, ele puder me ajudar na minha doença, ainda melhor, pois poderei viver, e ao lado dele. Cresceremos felizes juntos. Sim, quero muito um irmão. Meu irmão é meu herói, ele vai me salvar. Não morrerei graças a ele. Sou muito grata a ele por isso.

Desfecho favorável: Fiquei curada de minha doença, mas hoje também percebo que gerei muita tristeza e sofrimento para meu irmão caçula. Além disso, parece que o passado vem à tona como se fosse um fantasma para me assombrar. Não importa o que aconteça, sempre levarei este sofrimento junto comigo, acho que preciso tirar um tempo para mim, ficar longe de tudo e de todos.

Desfecho desfavorável: Só queria que minha mãe me deixasse descansar. Estou exausta de fazer tanta coisa e não melhorar, mas como faço para dizer isso a ela? Como faço ela perceber que não tem mais jeito? Não quero passar por mais procedimentos, nem que meu irmão sofra também. Ele foi gerado só porque meus pais não aceitam que não vou viver para sempre. Sabe, às vezes sinto que estou vivendo por eles e não por mim. Só queria poder aproveitar o tempo que me resta em paz, sem precisar estar em hospitais. Acredito que meus pais nunca irão me perdoar por ter feito eles sofrerem tanto por mim, gerado outra vida por mim e eu vou morrer do mesmo jeito.

\section{Irmão Salvador}

Por um lado, tenho uma missão muito grande aqui na Terra. Eu não a escolhi, escolheram para mim e, até hoje, não tive abertura para dizer minha opinião. Minha irmã tinha uma doença grave, eu nasci para salvá-la. Meus pais me fizeram em um laboratório, me programaram para nascer do jeito que queriam, como se fosse um robô. Será que eu existiria se minha irmã não fosse doente? Ou eu sou apenas uma coisa ou objeto para satisfazer a vontade dos meus pais? Será que eles realmente me amam? Desde quando eu era bebê, eles faziam procedimentos em mim e eu nem sabia o que estava acontecendo. Eu amo a minha irmã, não imaginaria minha vida sem ela, acho que ela pensa o mesmo, e sei que ela faria o mesmo por mim, mas me sinto usado pelos meus pais. Não me perguntaram se eu queria aquilo. Isso me deixa muito desconfortável e sinto como se fosse invisível. Só gostaria de ter o meu espaço na família. Às vezes, sinto que não fui desejado, só usado para salvar minha irmã mais velha, planejado por causa do amor que meus pais depositaram nela e não por me amarem e me desejarem. Também estou com medo de não conseguir e me sinto como um medicamento. Agora que minha irmã está prestes a partir, fico pensando qual será o meu papel na família. Meus pais vão me rejeitar por não ter conseguido cumprir meu objetivo aqui na Terra? Eu sou inútil? Estou perdido e confuso. Meus pais gostam mais da minha irmã do que de mim. Me pedem um monte de coisas enquanto ela não precisa fazer nada. Quero brincar com meus amigos e nunca tenho tempo, tenho que tirar sangue toda hora, por que eles não tiram o sangue deles? Eu não entendo. Sinto-me exausto diariamente, esgotado. Faço tudo o que posso para o bem de minha irmã, mas não os vejo fazer o mesmo por mim. Sinto-me cada dia mais pressionado. Parece uma obrigação. Sou novo para tanta responsabilidade. É como se minha vida não dependesse de mim. Por que eu? Não acho que vivo, apenas existo para manter a vida de outra pessoa. Cresci com o fato de ser a única salvação para minha família. Muita expectativa foi depositada sobre mim, afinal, eu tinha nascido para isso. Dessa maneira, me tornei uma pessoa extremamente ansiosa e com conflitos de relacionamento. Não consigo confiar nas pessoas e nem aceitar a demonstração de afeto delas por mim. Não acredito que seja natural e sempre espero que elas queiram um benefício em troca. Hoje, mudei de país em busca de uma nova vida, onde eu possa me encontrar, ser somente eu e não o medicamento da minha família. 
Por outro lado, se eu acho errado ter nascido para ajudar minha irmã? Não acho, gosto de saber que fui responsável por salvar a vida dela. Apesar de os procedimentos terem sido dolorosos e o sofrimento grande, acabou dando tudo certo, e se ela está viva é graças a mim. Ora, tantas pessoas são geradas por acidente e nem por isso reclamam. Prefiro bem mais ter nascido com um propósito nobre como o de ajudar minha própria irmã e salvar sua vida. Tem momentos de questões existenciais em que eu me pergunto por que não fui gerado apenas para ser eu, aí percebo como seria egoísta eu me importar tanto com isso. Afinal, salvei a vida de uma pessoa. Não só de uma pessoa qualquer; da minha irmã. Além disso, não foi só ela quem ganhou, eu ganhei uma irmã para me acompanhar para toda a vida, e ajudei também meus pais, ao não passarem pela dor horrível de perder um filho. É estranho pensar em como sou diferente das outras crianças porque eu nasci para salvar minha irmã. Muitos me perguntam como é saber que estou vivo hoje por ela. É tão legal poder ajudar minha irmã. Para mim, o que meus pais fizeram é a maior prova de amor. Eles dizem que todos os irmãos mais novos nascem para fazer companhia para os mais velhos, por isso, nós devemos nos proteger e cuidarmos uns dos outros e que papai do céu só deixa nascer quem for vir para ajudar o irmão em tudo o que for preciso. Meu maior medo é não conseguir salvá-la. Se esse dia chegar, eu sei que fiz tudo o que podia por ela. Tive uma infância muito feliz na presença constante de meus pais e minha irmã. Sempre fomos inseparáveis e isso me fez crescer aprendendo a valorizar a família e a união. Muitos de meus colegas na infância queixavam-se de serem filhos únicos e não terem uma companhia diária. Eu tinha/ tenho uma irmã um pouco debilitada pela doença, mas ela estava lá, dormindo e acordando em minha companhia, festejando aniversários e viajando com a família. Hoje, sou grato a Deus por tê-la comigo e é gratificante saber que eu pude ser a peça fundamental para a sua sobrevivência. Não viemos para este mundo a passeio, acredito que toda vida na Terra tenha um propósito, e o meu vem sendo concretizado com sucesso.

\section{Discussão}

O tema "saviour sibling" é bastante controverso, pois envolve questões acerca do diagnóstico genético préimplantacional (DGPI), suscitando discussões sobre os impactos físicos e psicológicos, além de seus limites éticos. No nosso caso clínico acima, os progenitores se depararam com a falta de compatibilidade com sua filha, o que os levou à realização do DGPI. Não há regulamentação quanto à questão no Brasil, sendo a única menção legal em vigor a resolução $n^{\circ}$ 2.121/2015 do Conselho Federal de Medicina, que permite a utilização das técnicas de reprodução humana assistida para a seleção de embriões compatíveis com o(a) filho(a) do casal já afetado por doenças que tenham como terapia o transplante de célulastronco ${ }^{13}$. É necessário um debate que envolva os aspectos bioéticos porque tal condição se depara com o peso moral da necessidade médica urgente de manter um paciente vivo e o desejo desesperado de pais que querem salvar a vida de seu filho. Em contrapartida, um ser humano nascerá sendo o foco das esperanças de seus pais, além de ser tratado como meio de cura - instrumentalizado. É fundamental, portanto, gerar discussões relacionadas ao impacto tanto familiar quanto na vida do bebê salvador ${ }^{6,14}$.

Os princípios bioéticos favoráveis ao DGPI incluem sobretudo o respeito à autonomia dos pais, além da beneficência ao filho portador de patologias atualmente tratáveis por meio desse procedimento 13 . Ademais, há um imperativo ético em salvar uma vida, o que, por sua vez, promoveria sensação de bem-estar pessoal ao novo filho gerado por ajudar o irmão doente ${ }^{2}$. Também se apresenta como melhor alternativa quando comparada à concepção natural, pois esta não garante a compatibilidade do filho doente com o bebê a nascer. Os argumentos contrários são baseados nos riscos aos quais é submetido o embrião, bem como a possibilidade do desenvolvimento de problemas psicológicos no doador e no irmão doente. Uma forma de compreender o princípio da justiça em toda sua complexidade seria dizer que o bem-estar de um sujeito não é mais importante que o bem-estar de outro $\frac{15}{15}$ e, no caso do saviour sibling, este certamente não tem os mesmos benefícios que os pais e o filho doente. Há que se mencionar também os riscos envolvidos com a própria técnica, a fim de não gerar danos para os envolvidos, principalmente o irmão doador, o que coloca em dúvida a vigência do princípio da não maleficência. Outro questionamento envolve o uso do DGPI para escolhas de características biológicas, como sexo ou cor dos olhos, por exemplo, o que poderia criar um cenário favorável para a teoria eugenista ${ }^{3,16}$ ter um campo para sua promoção e argumentos para seus defensores. 
Ou seja, se há a possibilidade de produzir um ser com determinado genótipo para se salvar um irmão doente, por que não estender essa possibilidade para o que se consideraria um aprimoramento genético da humanidade? O argumento da ladeira escorregadia (slippery slope) aponta para a seguinte situação: se se permite uma técnica " $A$ " qualquer, por que não se permitir o uso das técnicas subsequentes " $B$ ", " $C$ ", até a técnica " $Z$ ", sendo esta totalmente distante da técnica " $A$ " original? O ponto exato em que uma determinada técnica na sequência de $A$ a $Z$ perde sua validade moral e passa a ser inaceitável não há como se definir exatamente, no entanto, mesmo com todos os questionamentos que já foram apontados anteriormente, gerar um filho para tentar salvar outro é eticamente diverso de se selecionar todos os seres que terão direito à existência baseando-se em raça ou etnia, por exemploํ․ Mesmo assim, impossível não ficarmos alertas ao fato de que, diante do que os defensores deste pretenso aprimoramento causaram à Humanidade no século $X X$, o simples aceno a esta possibilidade nos faz temer o que o futuro pode reservar à Humanidade.

Prosseguindo nesta linha: uma determinada médica que auxilie um casal a tentar curar uma filha mediante um saviour sibling seria a responsável por práticas eugênicas? Frente à médica deste caso específico, conforme retratada, com todos seus questionamentos, sua preocupação de fazer o correto, de ser o mais justa possível, não seria o caso de se lançar mão da ética das virtudes, ou seja, considerá-la como portadora das características de um agente moral que a levam a agir para o bem, perseguindo determinados fins, no caso a beneficência para o casal e sua filha doente ${ }^{18,19}$ ?

No que diz respeito à individualidade da criança doadora e a coletividade representada na família, muitos estudos corroboram com a ideia de que as crianças são beneficiadas por existirem nessas unidades de família que necessitam de apoio mútuo e cooperação para prosperar, justificando, então, a criação de irmãos salvadores com base nos interesses coletivos da família e nos interesses individuais da criança ${ }^{3,4,112}$. É possível que a criança sofra psicologicamente tendo o conhecimento de que foi concebida para salvar a vida de outra pessoa. Parte das pessoas acredita nessa hipótese, enquanto outra parcela acha que a criança seria de fato beneficiada em ser selecionada dessa forma, argumentando que seria vantajoso no relacionamento com o irmão curado e com os pais que não iriam sofrer o luto ${ }^{3,4}$.

Há que se levar em conta também os aspectos relacionados à saúde física dos doadores, já que são submetidos a diversos procedimentos, como transfusões repetidas e até mesmo doações de órgãos ${ }^{12}$. Já quanto à idade de irmãos ao fazer a doação, adolescentes expressam mais satisfação quando comparados aos de menor idade ${ }^{11,20,21}$, estes sim os verdadeiros saviour siblings, gerados com a finalidade de salvar um irmão mais velho. Talvez isso possa ser explicado pela condição dos primeiros de nascer naturalmente e terem a função de doador somente mais tarde, ao invés de terem sido criados especificamente para essa função, além de muito provavelmente terem maior capacidade de compreensão para entender plenamente a real situação em que se encontram.

Outra questão importante é o acesso à informação. Com o avanço da tecnologia, novos procedimentos foram criados para garantir uma certeza maior na compatibilidade entre os filhos, mas são, muitas vezes, desconhecidos pelos pais e até por parte da comunidade médica. Isso abre um questionamento sobre a relação médico-paciente, em que poderia haver uma transmissão melhor de informação por parte dos médicos, com o objetivo de alertar e discutir com os pais sobre a questão dos tratamentos emergentes e, também, questões morais e éticas relacionadas ao assunto. Os médicos podem optar por não discutir opções terapêuticas com os pacientes ou com os pais destes por vários motivos, como falta de conhecimento ou questões pessoais. A ignorância da tecnologia, além da questão da disponibilidade e da avaliação adequada dos prós e contras, pode afetar nas atitudes de se escolher uma determinada opção de tratamento, mas não justifica a não divulgação de informação ${ }^{7}$. É importante apoiar ativamente pacientes a tomar decisões que mais os favoreçam, sem ferir sua autonomia. Alguns argumentam que o irmão salvador pode se beneficiar de uma doação bemsucedida, porém, uma doação fracassada pode ser traumática e a incerteza do resultado pode impactar negativamente a unidade familiar 22,23 .

Os benefícios para os pais e o filho doente são muito mais tangíveis do que aqueles atribuídos ao irmão doador, baseados no altruísmo retrospectivo e um benefício psicológico indireto ${ }^{3,4}$. É necessário pressupor que o irmão doador será altruísta o suficiente 
para ajudar o irmão, ferindo, então, a autonomia da criança a nascer e se contrapondo à não-maleficência e à beneficência, ao reduzi-lo a um mero objeto sem vontade e liberdade própria. Todas essas atitudes são calcadas na projeção paternal de que a criança salvadora irá se sentir bem por poder ajudar a salvar uma vida. Em contrapartida, o doador pode não querer ser submetido a inúmeros procedimentos, além da possibilidade de a doação fracassar e contribuir ainda mais para os prejuízos psicológicos a curto e longo prazo dessa criança22,23.

\section{Conclusão}

Este estudo explorou múltiplasquestões bioéticas relacionadas ao tema saviour siblings, abordando possíveis pensamentos e sentimentos de todos os envolvidos - pai, mãe, filho doente, irmão salvador e médico no intuito de promover reflexões relacionadas aos prós e contras frente à tomada de decisão de conceber um irmão salvador, além de concatená-las com a perspectiva bioética.

Faz-se necessário um debate mais aprofundado sobre o tema, enfatizando principalmente os possíveis benefícios para o concepto, uma vez que seus benefícios são muito mais subjetivos que os de seus pais e seu irmão já existente. A perda de autonomia do irmão salvador mencionada neste trabalho precisa ser enfoque de futuras discussões éticas a fim de proteger seus direitos.

O estudo da bioética por estudantes de medicina precisa ser considerado fortemente pelas faculdades, de modo a visar um futuro profissional capaz de lidar com situações não completamente compreendidas, buscando sempre não ferir os princípios bioéticos. Debates éticos dentro das salas de aula podem resultar em um pensamento mais amplo e completo das nuances e complexidade de diversas situações que um profissional pode enfrentar ao longo de sua carreira. Dessa forma, a relação médico-paciente se torna mais justa e gera enormes benefícios, tanto para os pacientes como para os próprios profissionais.

\section{Experiência do grupo na elaboração do trabalho}

Faz parte do trabalho a ser realizado na disciplina Seminário Integrado do sétimo período do nosso Curso de Medicina um item ao seu final que contemple a própria experiência dos alunos ao realizá-lo. Os autores deste artigo são sabedores de que este item habitualmente não faz parte de um artigo publicado. No entanto, pelas questões aqui levantadas que remetem à discussão sobre o processo de formação médica, os autores consideram importante destacálo como mais um item ao invés de distribuir o que aqui se encontra nos itens anteriores.

Face ao processo de humanização que vem sendo proposto aos profissionais de saúde, caracterizado por uma tentativa de melhorar a relação médico-paciente e nossa própria relação com temas como a morte, a doença e questões éticas presentes no dia a dia da prática médica, a Bioética caracteriza-se como elemento de extrema importância. Nesse contexto, é fácil visualizar como cursar essa disciplina foi impactante para nós. O sentimento após cada aula, texto, filme e reflexão era de crescimento pessoal através do aprendizado, e isso foi experimentado ainda mais intensamente na realização deste trabalho.

A maioria do nosso grupo não conhecia o tema deste artigo ou nunca tinha parado para pensar nele com profundidade. Após uma longa discussão, pois eram muitos os temas interessantes que poderiam ser abordados dentro do campo da bioética, chegamos à nossa escolha final: saviour siblings e suas questões bioéticas. Algo interessante a ser notado é que de início parecíamos muito convictos de nossas opiniões a respeito da produção de um "irmão salvador", porém, quanto mais discutimos sobre o tema, mais incertos ficávamos, mais lados da mesma questão nós víamos.

A proposta de nos colocarmos no lugar de cada uma das pessoas envolvidas no caso clínico - mãe, pai, filha doente, filho salvador e médica - nos defrontou com as razões e os sentimentos de cada um deles e nos permitiu perceber a complexidade do tema. $\mathrm{E}$ isto ficou ainda mais evidente quando cotejamos o que 
cada um de nós pensou e escreveu com os textos dos colegas. O resultado foi o aprendizado de não ficarmos fechados em nossos próprios (pre)conceitos e de abrir nossos olhos e ouvidos para quem pensa diferentemente de nós, atributo indispensável para nosso futuro ofício.

Além disso, a chance de elaboração de algumas cenas teatrais para a apresentação do trabalho nos deu oportunidade de explorar nosso lado artístico e criativo, além da diversão que nos proporcionou. Fazemos questão de destacar este último aspecto por acreditarmos que o aprendizado de Medicina se dá de forma mais integral e significativo se conseguimos aliar esforço e prazer ${ }^{24}$.

\section{Contribuições dos autores}

Zaidhaft S foi responsável pela concepção e orientação do projeto, e revisão final do artigo. Garcia L e Da Silva T foram responsáveis pela concepção do projeto. Pillar A, Daher A e Peçanha $F$ foram responsáveis pela redação do projeto. De Barros $A C$, Junqueira $A C$ e Do Lago $E$ foram responsáveis pelo debate e discussão do tema. Barbosa F, Leandro I, Da Cruz M e Saab R foram responsáveis pela redação do artigo.

\section{Conflitos de interesses}

Nenhum conflito financeiro, legal ou político envolvendo terceiros (governo, empresas e fundações privadas, etc.) foi declarado para nenhum aspecto do trabalho submetido (incluindo, mas não se limitando a subvenções e financiamentos, participação em conselho consultivo, desenho de estudo, preparação de manuscrito, análise estatística, etc.).

\section{Referências}

1. Côté S, Ravitsky V, Hamet P, Bouffard C. Between usage and polemic, an argument in favour of clarifying the terminology for preimplantation genetic diagnosis. J Int Bioethique Ethique Sci. 2015;26(4):137-50.

2. Restrepo PA, Abad PJS, Pastor LM. Diagnóstico genético preimplantatorio y el «bebé medicamento»: criterios éticos encontrados en la literatura biomédica y bioética. Cuad Bioét. 2012;23:301-320.
3. Madanamoothoo A. Saviour-sibling and the psychological, ethical and judicial issues that it creates: should English and French legislators close the Pandora's Box? Eur J Health Law. 2011;18(3):293-303. doi: 10.1163/157180911×574119

4. Taylor-Sands M. Saviour siblings and collective family interests. Monash Bioeth Rev. 2010;20(2)1-15. doi: 10.1007/BF03351522

5. Kakourou G, Vrettou C, Moutafi M, Traeger-Synodinos J. Preimplantation HLA matching: The production of a Saviour Child. Best Pract Res Clin Obstet Gynaecol. 2017;44:76-89. doi: 10.1016/j. bpobgyn.2017.05.008

6. Sparrow R, Cram D. Saviour embryos? Preimplantation genetic diagnosis as a therapeutic technology. Reprod Biomed Online. 2010;20(5):667-74. doi: 10.1016/j.rbmo.2009.12.015

7. Strong KA. Informing patients about emerging treatment options: creating "saviour siblings" for haemopoietic stem cell transplant. Med J Aust. 2009;190(9):506-7. doi: 10.5694/j.13265377.2009.tb02531.x

8. Marcotty J. 'Savior sibling' raises a decade of life-and-death questions: The method used at the $U$ to save Molly Nash's life is mainstream now, but the larger ethical issues are as urgent as ever. Star Tribune. [Internet]. 2010 [acesso em 2019 set 5]. Disponível em: http://www.startribune.com/savior-sibling- raisesa-decade-of-life-and-death-questions/103584799/

9. Cherkassky L. A Gift or a Waste? Quintavalle, Surplus Embryos and the Abortion Act 1967. New Bioeth. 2017;23(2):138-146. doi: 10.1080/20502877.2017.1345089

10. Cherkassky L. The Interfamilial Principle and the Harvest Festival. Eur J Health Law. 2016;23(1):61-79. doi: 10.1163/15718093-12341379

11. Cherkassky L. Gillick, bone marrow and teenagers. Med Leg J. 2015;83(3):154-8. doi: $10.1177 / 0025817215579170$

12. Jackson E. A response to Saviour Siblings: A Relational Approach to the Welfare of the Child in Selective Reproduction. J Med Ethics. 2015;41(12):929-30. doi: $10.1136 /$ medethics-2014-102606

13. Conselho Federal de Medicina. Resolução CFM N ${ }^{\circ} 2.121 / 2015$, Brasília, 16 jul. [Internet]. 2015. [acesso em 2019 out. 9]. Disponível em: http://www.portalmedico.org.br/resolucoes/ CFM/2015/2121_2015.pdf

14. Cardin VSG, Cazzelato CEC, Guimarães NCB. Do bebê medicamento sob o enfoque do biodireito e da bioética. Meritum. 2018;13(1):169-195. doi: 10.46560/meritum.v13i1.5878 
15. Rachels J. Ethical theory and bioethics. In: Kuhse H, Singer P., editors. A companion to bioethics. Malden: Blackwell Publishing Ltd; 2001.

16. Wilkinson S. Do we need an alternative 'relational approach' to saviour siblings? J Med Ethic. 2015;41(12):927-928. doi: $10.1136 /$ medethics-2014-102604

17. Hartogh GD. The slippery slope argument. In Kuhse H, Singer P., editors. A companion to bioethics. Malden: Wiley-Blackwell; 2001.

18. Dall`agnol D. Bioética. Rio de Janeiro: Jorge Zahar; 2005.

19. Oakley J. A virtue ethics approach. In: Kuhse, H, Singer P., editors. A companion to bioethics. Malden: Wiley-Blackwell; 2001.
20. Selgelid MJ. A relational approach to saviour siblings? J Med Ethics. 2015;41(14): 924-925. doi: 10.1136/medethics-2015-103256

21. Taylor-Sands M. Response to 'A relational approach to Saviour Siblings?' by Selgelid. J Med Ethics. 2016;42(10). doi: $10.1136 /$ medethics-2016-103453

22. Taylor-Sands M. Saviour Siblings: reply to critics. J Med Ethics. 2015;41(12):933-934. doi: 10.1136/medethics-2014-102607

23. Gavaghan C. Saviour siblings: no avoiding the hard questions. J Med Ethics. 2015;41(12):931-932. doi: $10.1136 /$ medethics-2014-102605

24. Zaidhaft S. A saúde mental dos estudantes de medicina: reminiscências e conjecturas de um mestre-escola. Rev Med. 2019;98(2):86-98. doi: 10.11606/issn.1679-9836.v98i2p86-98 